\title{
Online Learning Space and Wisdom Teaching
}

\author{
Yanxia $\mathrm{Wu}^{1}$ \\ ${ }^{1}$ Institute of humanities, Jiangxi University of Traditional Chinese Medicine, Nan chang, China
}

\begin{abstract}
Online Learning Space is a virtual learning environment which has evolved with the development of information technology and the continuous deepening of educational concepts. The wisdom teaching is a teaching by using teaching methods and teaching strategies rationally based on the Online Learning Space,to complete the transition from knowledge to wisdom,so that students can become intelligent talents. The wisdom teaching has two goals: to promote the individual growth and to foster innovative talents. Online Learning Space in different stages provides different support for Wisdom teaching activities, and realizes the goal of Wisdom teaching in different degrees.
\end{abstract}

\section{INTRODUCTION}

The study mainly studied two questions: What is the goal of Wisdom Teaching? What kind of support can the Online Learning Space provide for Wisdom Teaching activities?

\section{RESEARCH STATUS AT HOME AND ABROAD}

\subsection{Research Status At Abroad}

The research on Learning Space started in 2003 at abroad, mainly exploring how to reform school environment to meet the learning needs of the "Digital Generation". At present, the research of Learning Space includes all aspects of the learning ranging from the planning, design, implementation to evaluation of learning , and the developed countries such as the United States, Britain and Australia have all done useful attempts.

American scholar Brown (Brown, 2005), based on the characteristics of new learners, has made clear the design principles, technology configuration and related learning styles of Learning Space. The book " Learning Space" published by EDUCAUSE, a research institute of higher education in the United States, is the first monograph to introduce Learning Space systematically in 2006. It expounds the trend of Learning Space design from three aspects: the change of students, the development of technology and the understanding of learning. Subsequently, Australian Professor David (Radcliffe, 2008) proposed a "pedagogies-learning-space-technology (PST)" framework for Learning Space design and evaluation. He regards information technology, teaching method and Learning Space as the three elements of learning space design. He thinks that the three interact with each other. Teachers should pay full attention to the role of the interaction among the three in classroom teaching. Proper combination of a variety of factors can promote efficient learning. In 2010, the British Learning Technology Association released the Research Report on "Design Guidelines for Learning Space in the 21st Century,"which pointed out that Learning Space is a priority for future research. The Learning Space can be summarized by four key words: motivation, collaboration, personalization and flexibility; learning space should stimulate students' learning motivation, support students' collaborative learning, provide students with a personalized environment, and make a flexible change about space layouts to meet the needs. With the publication of "Learning Space Journal " at the University of North Carolina in 2011, the learning space research, as an important aspect of learning environment research,has drawn increasing attention from researchers, practitioners and policymakers in the world. The research and practice on Learning Space from the United States, Britain and Australia shows that Online Learning Space refers to the entire school space, including not only classrooms, libraries, outdoor learning area and other physical space, but also the school virtual space, we can say that Learning Space is the integration of an educational institution of physical space and virtual space.

The concept of Learning Space is gradually evolving from the original formal and physical environment to the informal, virtual digital learning environment, and then to the current Online Learning Space. Research on Online Learning Space abroad mainly focuses on the concept and description, design concepts and ideas, platform development and design, teaching applications, etc., emphasizing "learner-centered ", "learners take the

*Corresponding author:wuyanxia2000@sina.com 
initiative to create content ", and "learners make an interactive conversation with other learners ". For this learner-center Online Learning Space, Stephen Downes defines it as a combination of a tool, a service, a person, and a resource etc.

\subsection{Research status in China}

The literature number of domestic Online Learning Space is relatively small. with "Online Learning Space " as the title for searching on CNKI, there are 161 articles retrieved.

Table 1. Number of papers published over the years

\begin{tabular}{|c|c|c|c|c|c|c|c|c|}
\hline Year. & 2010. & 2011. & 2012. & 2013. & 2014. & 2015. & 2016. & 2017. \\
\hline Number of papers. & 1.1 & 1.1 & 2.1 & 18. & 24. & 30.1 & 62. & 22. \\
\hline
\end{tabular}

As can be seen from Table I, the study of Online Learning Space in China has only received academic attention in recent eight years. The document first appeared in 2010. At this time, Liu Haitao and Yu Jiao, a modern education technology center of Central South University, pioneered the construction of an Online Learning Space suitable for students' individual learning. From 2010 to 2012, there were only 4 relevant literatures. It is clear that Online Learning Space of this stage has not aroused much attention from the academic community.As can be seen from the table I, since 2013, the number of literatures has increased rapidly, and Online Learning Space has drawn more and more attention. Driven by the "three links and two platforms" policy, the Online Learning Space has become increasingly active, and a great deal of relevant research has emerged. By analyzing the research content of the literature, it can be seen that at present, there is not a unified understanding of Online Learning Space in the field of domestic research and practice. The main reasons are: (1) there is no consensus on the connotation of Online Learning Space; (2) the definition of the components of Online Learning Space is unclear. This leads to a certain confusion of understanding. The connotation and elements of Online Learning Space guide practice. The clearer the connotation and constituent elements of Online Learning Space are, the more targeted the construction is, the more effective the implementation will be. In the "13th Five-Year Plan" period, under the background of "Online Learning Space for all", it is particularly necessary to make a comprehensive discussion about these problems.

\section{THE CONNOTATION OF ONLINE LEARNING SPACE}

Online Learning Space is a virtual learning environment which has gradually evolved with the development of information technology and the continuous deepening of educational concepts. When it comes to the connotation of the Online Learning Space, basically two views are presented.The broad Online Learning Space refers to a virtual space that runs on any platform carrier to supports online teaching activities. The narrow sense of
Online Learning Space refers to the special educational service platform, which supports online teaching activities. It provides an online platform for various space services such as student space, teacher space, parental space,manager space, and institutional space. The object of this study is a broad Online Learning Space. Information technology refers to a system of means and methods for collecting, processing, storing, communicating, and applying information. With the continuous development of information technology, the representing methods of online learning resource, learning services methods, and human-computer interaction methods are continuously evolving, and the form of Online Learning Space is constantly changing and its functions are constantly improving accordingly. Therefore, in the different stages of information technology development, the connotation of Online Learning Space is different. This article will discuss the connotation of Online Learning Space from the three stages of information technology development: Web1.0, Web2.0, and Web3.0.

Table 2: The connotation of online learning space

\begin{tabular}{|l|l|l|l|}
\hline $\begin{array}{l}\text { Information } \\
\text { Technology } \\
\text { Development }\end{array}$ & \multicolumn{3}{|l|}{ The connotation of online learning space } \\
\cline { 2 - 4 } & $\begin{array}{l}\text { representing } \\
\text { methods of } \\
\text { resource }\end{array}$ & $\begin{array}{l}\text { learning } \\
\text { services } \\
\text { methods }\end{array}$ & $\begin{array}{l}\text { human-computer } \\
\text { interaction }\end{array}$ \\
\hline H'eb1.0 & $\begin{array}{l}\text { multi-media } \\
\text { resources }\end{array}$ & $\begin{array}{l}\text { A large number } \\
\text { of lnowledge } \\
\text { database }\end{array}$ & $\begin{array}{l}\text { Digital } \\
\text { education } \\
\text { resources are } \\
\text { one-way } \\
\text { process }\end{array}$ \\
\hline "ieb2.0 & $\begin{array}{l}\text { Multi-media } \\
\text { resources are } \\
\text { becoming open } \\
\text { and } \\
\text { generative. }\end{array}$ & $\begin{array}{l}\text { The } \\
\text { ubi quitous, } \\
\text { mobile, and } \\
\text { instant } \\
\text { learning } \\
\text { platform }\end{array}$ & $\begin{array}{l}\text { Various } \\
\text { interactive } \\
\text { environment }\end{array}$ \\
\hline "heb3.0 & $\begin{array}{l}\text { Digital } \\
\text { education } \\
\text { resources are } \\
\text { more } \\
\text { personalized } \\
\text { and adaptable. }\end{array}$ & $\begin{array}{l}\text { multi-synergy } \\
\text { virtual } \\
\text { integrated, } \\
\text { and accurate } \\
\text { learning } \\
\text { platform }\end{array}$ & $\begin{array}{l}\text { high-immersion } \\
\text { and contextual } \\
\text { learning } \\
\text { experience } \\
\text { environment }\end{array}$ \\
\hline
\end{tabular}

\section{THE TECHNICAL SUPPORTS FOR WISDOM TEACHING PROVIDED BY THE ONLINE LEARNING SPACE}

The wisdom teaching is a teaching by using teaching methods and teaching strategies rationally based on the Online Learning Space,to complete the transition from knowledge to wisdom,so that students can become intelligent talents. The wisdom teaching has two goals: to promote the individual growth and to foster innovative talents. Online Learning Space in different stages provides different support for Wisdom Teaching activities, and realizes the goal of Wisdom Teaching in different degrees.

To study the support for wisdom teaching activities provided by the Online Learning Space, it is critical to analyze the support services that the online learning space provides for the core elements of teaching activities. The Online Learning Space is a virtual learning 
environment that has gradually evolved with the development of information technology. The Online Learning Space is a space that supports teaching and learning innovation. With the support of the Online Learning Space, the teaching goal is constantly changing from mastering knowledge to developing wisdom.The teaching resources are no longer limited to traditional textbooks and become an online learning platform built by experts, teachers, and students. Teachers will become the leader in acquiring resources, counselors in selflearning, guides in deconstructing and reconstructing, and promoters in communicating. Students will become the subject of learning. With the support of the Online Learning Space, the development direction of Wisdom Teaching is as follows:

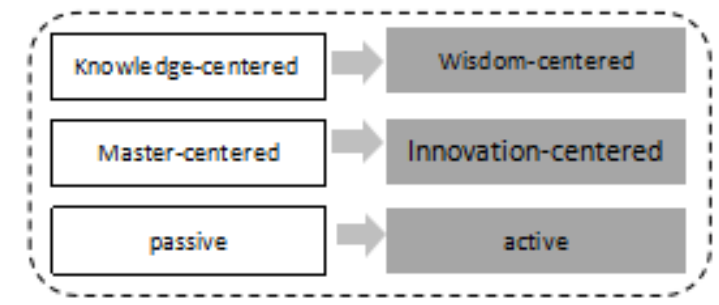

Traditional teaching value knowledge and leave out wisdom. With regard to the relationship between knowledge and wisdom,Dewey, an American educationalist, holds that knowledge is the learning that has been acquired and stored, while wisdom is the ability to use knowledge to guide life and improve life. With the support of an increasingly sophisticated Online Learning Space,the narrow goals of acquiring knowledge has been transferred to the innovative goals of wisdom development; classroom teaching based on imparting, comprehending and memorizing knowledge is changing to develop students' ability of innovation and creativity.All the time, Students have always been passive recipients in the classroom. With the development of Online Learning Space, students have more opportunities for independent learning, more convenient access to resources and learning tools, and greater power to organize and develop individual learning plans.

\section{CONCLUSIONS}

At present, the development of Online Learning Space is in full swing, but its application is still relatively primary and fragmented, which fails to integrate effectively with teaching practice and lacks a feasible normal application model. The full realization of wisdom teaching will still take time.

\section{REFERENCES}

1. Wang Shizeng.Research on the construction of teachers' personal space based on network teaching and research platform $[\mathrm{J}]$. China Electrochemical Education, 2012, (11): 140-142.
2. Huang Lihua, Zhou Yifa, Chen Xuejun. The construction of class network learning space under the background of Banban Tong [J]. China Electrical education, 2014, (3): 86-90.

3. Wu Zhongliang, Zhao Lei. A preliminary study of the overturned classroom teaching model based on the network learning space $[\mathrm{J}]$. China Electric education, 2014, (4): 121-126.

4. Bi Jiajuan, Yang Xianmin. Construction of personal learning space from the perspective of communicationism $[\mathrm{J}]$. China Electrochemical Education, 2014, (8): 48-54.

5. Zhang Shiming, Xu Hexiang, Qian Dongming, et al. Analysis of "Network Learning Space All-Access" System in Cloud Architecture Mode [J]. Journal of East China Normal University (Natural Science Edition), 2014, (2): 30-39.

6. Zhu Zhiting, Guan Jueqi . "The construction framework ofOnline Learning Space for all" [J]. China Electrochemical Education, 2013, (10): 1-7.

7. Zhu Zhiting, Guan Jueqi, Liu Jun. Personal learning space: new focus of digital learning environment design [J]. China Electrochemical Education, 2013, (3): $1-6$.

8. Whiteside, A., Brooks, D.C., \& Walker, J.D.. Making the case for space: three years of empirical research on formal and informal learning environments [J/OL]. EDUCAUSE Quarterly, 2010, 33(3).

9. Radcliffe, D. A Pedagogy-Space-Technology (PST) Framework for Designing and Evaluating Learning Places [A].Proceedings of the Next Generation Learning Spaces Colloquium [C].Brisbane:The University of Queensland,2008. 916.

10. Astrid M. Sølvberg and Marit Rismark. Learning spaces in mobile learning Environments[J].Active Learning in Higher Education, 2012,13(1) :23-33. 